\title{
Oral Communication Strategies Training: The Case of Pre- Service English Teachers in Indonesia
}

\author{
Noor Rachmawaty ${ }^{1}$, Aridah $^{2}$, Weningtyas Parama Iswari ${ }^{3}$, Syamdianita $^{4}$ \\ Universitas Mulawarman, Indonesia ${ }^{1,2,3,4}$ \\ Email Correspondence: itaw75123@yahoo.com
}

Background:

Many researches on pre-service English teachers have been carried out in various aspects, from teaching techniques to psychology. However, research on oral communication strategies of pre-service English teachers is still little done. This study delved into the effect of oral communication strategies training on pre-service English teachers' speaking performance. In addition, it revealed the relationship between gender and types of oral communication strategies.

Methodology:

This study involved 27 students who joined in Speaking III course. The OCSI as the instrument in this study consisted of eight categories of strategies for coping with speaking problems and seven types for dealing with listening problems

Findings:

Results from descriptive statistics showed that before the training, message reduction mainly was used while social affective and attempt to think in English was the least often employed strategy for resolving speaking difficulties. Meanwhile, after the training, a Non-verbal strategy while speaking was frequently used by the students. Message abandonment became the least used strategy after training was implemented. In dealing with listening problems, before the training, Non-Verbal strategies while listening was mostly used while the least used strategy was getting the gist. After the training, Word oriented became the most often employed technique Meanwhile, strategies for preserving fluency were the least frequently adopted.

\section{Conclusion:}

The MANOVA results of data analysis revealed that female students significantly performed better in speaking English than male students. However, there was no significant difference in Oral Communication Strategy used between male and female students.

Keywords: oral communication strategy training; speaking; pre-service english teachers.

DOI $\quad$ : http//dx.doi.org/10.24903/sj.v6i2.799

\begin{tabular}{|c|c|c|}
\hline Received & : & August 2021 \\
\hline Accepted & : & September 2021 \\
\hline Published & : & October 2021 \\
\hline Copyright Notice & : & $\begin{array}{l}\text { Authors retain copyright and grant the journal right of first publication with the } \\
\text { work simultaneously licensed under a Creative Commons Attribution } 4.0 \\
\text { International License that allows others to share the work with an acknowledgement of } \\
\text { the work's authorship and initial publication in this journal. } \\
\text { cc) () () }\end{array}$ \\
\hline
\end{tabular}




\section{INTRODUCTION}

In English as a foreign language, where not many people use that in daily communication, speaking in English is a challenging task for learners whose background language is not English. Compared to other language skills, in foreign language contexts, speaking skills are still considered to be a difficult skill to master, even though learners have undertaken years of classroom instruction as well as experiencing different kinds of methodological approaches in an attempt to improve the process of foreign language acquisition and the ability to use the language to communicate. In Indonesia, the teaching of English is directed to encourage students to use language in communication successfully or, in other words, they have adequate ability to communicate using English in various communicative situations. However, previous studies found that students' oral production is unsatisfactory (Cahyono \& Widiati, 2008; Setiyadi, 2009; and Rachmawaty \& Hermagustiana, 2010). In line with the previous findings, Thalal (2010) stated that there are many cases where students' expectations do not match the reality of learning results showing that their English proficiency is still very low or no significant English ability after many years of study.

Knowing that communicating in a foreign language is a complex, multi-faceted skill, it is necessary to consider action to help students improve their oral communication skills so that they can involve fluently in different sets of communication tasks. Concerning the adequate level of oral production skills to communicate smoothly, it is English teachers whose expertise can be taken into account to speed up students' language mastery as they are the agent of knowledge transfer. Conversely, if English teachers lack expertise and mastery of language skills themselves, they may not be progressing well. In order to teach efficiently, a foreign language teacher should have subject knowledge (Shin, 2008) which contains, apart from proficiency in the target language, a range of pedagogical, curricular, and cultural awareness (Pachler, Evans, \& Lawes, 2007). In a more specific point, Bachman (1990) points out that in foreign languages, subject knowledge of instructors includes language proficiency, which refers to the knowledge, competency, or capacity to utilize a language. Consequently, a foreign language teacher has to understand the language system and use the knowledge in actual speech production and comprehension. 
The English department is the department in the faculty of education that produces English teachers who will teach for elementary to secondary levels. Students in the faculty of education are generally called pre-service teachers. This group can also find problems related to oral communication, even though their major is English. Sayuri (2016) conducted a qualitative study involving the fourth-semester students of the English Department. The result shows that the students faced some problems related to pronunciation, fluency, grammar, and vocabulary. Additional findings from the questionnaire revealed that Students encountered additional difficulties, including lack of self-confidence, shyness to talk, fear of making mistakes, nervousness, and having nothing to say. Following that, other variables contribute to difficulties communicating with pupils, including a lack of reading habits, uneven involvement and English practice both within and outside the classroom, and confusion about applying grammar rules.

Concerning problems related to speaking, Scarcella \& Oxford, (1992) point out that the condition arises from the somewhat unreal and comparatively safe context of the classroom where teacher-student and peer interactions are restricted to essential patterns and prefabricated situations or topics. Meanwhile, in real-life interactions, a significant factor for second language acquisition and the development of communicative competence "demands a great deal of spontaneity and the ability to cope with the unexpected" (Peloghities, 2006, p.48). In certain authentic communicative situations, language learners are often unable to retrieve a word, use or comprehend an idiomatic expression, or grasp a topic; consequently, communication breaks down (Willems, 1987). Therefore, they must develop specific communication strategies that compensate for their target language deficiencies, enhance interaction in the target language, and eventually develop communicative competence (Willems, 1987; Bialystok, 1990; Dornyei, 1995).

The importance of Communication Strategies (CS) was also addressed by Candlin (1983), who contends that when entering communication situations outside the classroom, many students encounter problems and difficulties in fully expressing their meaning due to deficiencies or gaps in their linguistic skills knowledge. Communication Strategies, therefore, represent a valuable tool to enable students to cope with these potential problems and develop their communicative competence (Canale \& Swain: 1980). 
Referring to the definition and its role for a language learner, Communication Strategies emerge as one of the most popular issues to be explored. The issue of communication strategy use and its relation to foreign language fluency and communicative effectiveness thus deserves further in-depth investigations. Extensive studies related to CS were conducted mostly about students' proficiency level, task-based activities, and Individual differences. Results from the studies show that elementary-level students frequently used the strategies that impeded their communication flow. On the other hand, advanced students mostly employed strategies to maintain interaction flow (Nakatani, Makki and Bradley, 2012). Previous studies in oral communication strategies conducted in the Indonesian context focused on the frequency and types of oral communication strategies used (Sukirlan, 2014; Aziz, Fata, \& Balqis, 2018). Speaking performance, gender and the pre-service teachers' view on oral communication strategies have been under-explored. Therefore, it can be illuminating to further research in this very field.

Taking into account the foregoing, which emphasizes the critical nature of teachers' language proficiency for foreign language teachers and the difficulties encountered by preservice teachers in speaking English, this study intends to inquire the effect of oral communication strategies training on pre-service English teachers' speaking performance and how gender relates to the use of oral communication strategies. This study also explores the views of pre-service EFL teachers about the implementation of oral communication strategies training.

The following issues were addressed in this paper: (1) What is the pre-service English teachers' speaking performance before and after the oral communication strategy training? (2) What are the oral communication strategies used by the pre-service English teachers before and after oral communication strategy training? (3) Is there any significant effect of oral communication strategies training on the speaking performance of the pre-service English teachers? (4) Does gender difference affect the use of oral communication strategies? (5) What are the perceptions of pre-service English teachers in relation to the implementation of oral communication strategies training?.

\section{METHODOLOGY}

For the purposes of the current research, mixed methods triangulation design (quantitative dominant) was used to investigate the questions formulated in this study. By implementing this method, the researcher could obtain different but complementary data on the same topic (Morse, 1991) to understand the research phenomenon better. Creswell \& 
Clark (2007) pointed out that the triangulation design is a convergence model on the same view. The researchers aimed to validate, confirm or corroborate quantitative results with qualitative findings.

In this study, whether the oral communication strategies training had an effect on preservice English teachers' speaking performance was investigated with the quantitative research design with a pretest-posttest model. While qualitative design was used to explore the pre-service English teachers' view on the implementation of oral communication strategies training. The type of mixed-method design that the researchers applied in this study is in the explanatory design. The quantitative and qualitative data were collected and analyzed in sequence: quantitative data was collected and analyzed first then followed by the qualitative data. The research design is shown symbolically in Figure 1.

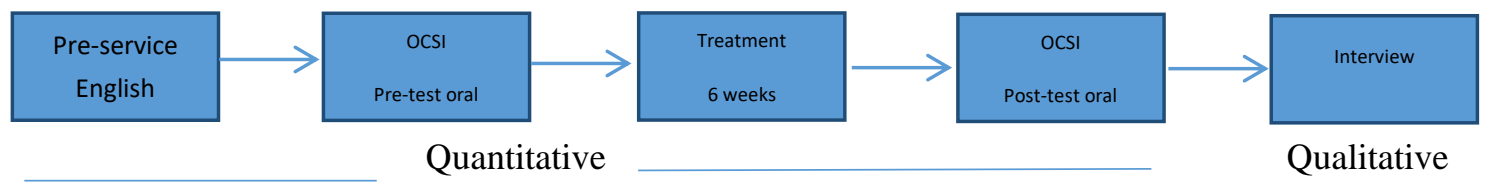

Figure 1. Research design

\subsection{Sample / Participants}

This research was experimental and involved 27 pre-service English teachers majoring in English at Faculty of Education, Mulawarman University. Their age range was from 19-22 years old. The reason for taking this group was due to the amount of time they have spent in the university, which helped them become familiar with different kinds of activities in speaking class. Having this experience, it is assumed that they had an adequate level of confidence in expressing their ideas. Thus it gave more opportunities for the researchers to elicit communication strategies from their utterances.

\subsection{Instruments}

Data were collected using three instruments, they were:

a. Oral Communication Strategy Inventory (OCSI)

The first instrument is Oral Communication Strategy Inventory (OCSI), a questionnaire that identifies the participants' oral communication strategies. The questionnaire was developed by Nakatani (2006), combining features from many major taxonomies of CS into a self-reporting questionnaire. He retains the distinction between reduction and achievement strategies whilst also separating strategies into speaking and listening factors, reflecting the interactive nature of foreign language communication. The questionnaire consists of 32 items for coping with speaking problems and 26 items for coping with listening problems during communication 
tasks. It is a 5-Likert scale questionnaire. It was estimated that the participant completed the questionnaire in 20 minutes. They were instructed to give a check $(\sqrt{ })$ in the space after each item.

b. Oral Fluency Test

The next instrument was the oral fluency test adopted from the test developed by Khan (2010). It has three communicative tasks: personal details (3 minutes) and description (3 minutes). Both OCSI and Oral Fluency test were given before and after the treatment.

c. Interview Guide

The last instrument for collecting the data is the interview guide, which consists of questions focusing on students' attitudes and experiences during oral communication strategies training. The semi-structured interview is the most used type (Richards, 2009). This format needs an 'interview guide' that must be made and piloted in advance (DÖrnyei, 2007). In addition, he mentions that although there is a set of preprepared guiding questions, this interview form would not limit the depth and breadth of the respondents story. In other words, the researcher understands phenomena under investigation; nevertheless, she allows the interview participants to develop their own stories even though unexpected answers/responses would be covered up in the interview.

\subsection{Data collection procedures}

The quantitative data were gathered from the OCSI questionnaire and the oral fluency test. The qualitative data were gathered from the interviews with purposively selected preservice English teachers. The quantitative part of this study was the experimental phase where researchers included the oral communication strategies training for six weeks in Speaking III course. In order to reveal the pre-service teachers' views while the oral communication strategy training was included in the course, an interview with four students was conducted. This part was considered the qualitative part as it explored deeper how the training may affect the pre-service English teachers' oral communication strategies. Before treatments were conducted, the researchers collaborated with lecturer taught Speaking III course to adjust the oral communication strategies plan for six meetings with the prepared course outline designed by the Speaking III lecturer. The course aimed at developing students in using different types of language functions, such as: asking for and giving advice, suggesting, encouraging, persuading, and complaining in group discussion, debate, and role 
play. In addition, students were encouraged to practice and distinguish between yes/no questions and wh-questions.

\subsection{Data analysis}

Descriptive data (mean and S.D) from OCSI were used to identify the participants' frequency and range of communication strategies. Features and frequencies of oral communication strategies before and after the treatment will be identified from the result of the speaking test. In order to assess the overall speaking performance of the participants, a speaking assessment rubric was used. To know the effect of oral communication strategies training on speaking performance, the data was analyzed by using Repeated measure MANOVA. To help the calculation, the application of SPSS version 20 was used for the quantitative data analysis.

The content analysis was used to analyze the participants' responses regarding their attitudes and experiences on the application of oral communication strategies training According to O'connor et al., (2006), content analysis is technique for gathering and analyzing the content of the text. Meanwhile, Silverman (2001) describes that content analysis involves establishing categories and counting the number of instances when those categories are used in a particular text item. Thus, in this study the researcher categorized pre-service English teachers' views when the oral communication strategy training was implemented with regards to their attitudes and experiences.

\section{FINDINGS}

The Results will be presented following research questions formulated in this study.

\subsection{What is the speaking performance of the pre-service English teachers before and after the implementation of oral communication strategy training?}

For the purpose of statistical analyses, the results from students' responses on OCSI questionnaire and speaking test were converted in order to make interpretation of the results easier. In addition, students in this study were classified as having one to five levels of classifications. The level of classification was used for classifying the students' Oral Communication Strategy (OCS) use and Speaking ability. Students with overall score between 0 - 20 were classified as Very Low. Students who got score between 21- 40 fell in the Low category. The next classification is Medium which classified the students' score from 41 - 60. Students whose score between 61 - 80 were assigned in High level and the last level is Very High for those who got score between $81-100$. 
Table 1. shows general descriptions for students' speaking score and oral communication strategy use before and after oral communication strategy training was included in Speaking III course.

Table 1 Students' Speaking Score

\begin{tabular}{lccccc} 
Variable & N & Min & Max & Mean & Std Dev. \\
\hline $\begin{array}{l}\text { Speaking } \\
\text { (Before) }\end{array}$ & 27 & 44.00 & 80.00 & 64.74 & 11.04 \\
$\begin{array}{l}\text { Speaking } \\
\text { (After) }\end{array}$ & 27 & 48.00 & 84.00 & 68.00 & 10.47 \\
$\begin{array}{l}\text { OCS } \\
\text { (Before) }\end{array}$ & 27 & 44.40 & 79.74 & 61.54 & 8.87 \\
$\begin{array}{l}\text { OCS } \\
\text { (After) }\end{array}$ & 27 & 40.52 & 84.04 & 65.41 & 10.79 \\
\hline
\end{tabular}

Table 1 shows the average score of students' speaking test before oral communication strategy was included in Speaking III course. The average score was lower (64.74) than after the training $(\mathrm{M}=68.00)$. Students' responses on the use of oral communication strategies showed a slight increase on the mean score before the training $(M=61.54)$ and after the training $(M=65.41)$.

The frequency of students' speaking score before oral communication strategy training was ranging from medium to high as shown in table 2. There were 16 students (59.26\%) got high score and $11(40.74 \%)$ were in medium level.

Table 2 The description of students' speaking score before OCS training

\begin{tabular}{ccccc}
\hline & Speaking & & & \\
\cline { 1 - 2 } Interval & Category & Frequency & Percentage (\%) \\
\hline $80<\mathrm{X} \leq 100$ & Very High & 0 & 0 \\
$60<\mathrm{X} \leq 80$ & High & 16 & 59.26 \\
$40<\mathrm{X} \leq 60$ & Medium & 11 & 40.74 \\
$20<\mathrm{X} \leq 40$ & Low & 0 & 0 \\
$0<\mathrm{X} \leq 20$ & & Very Low & 0 & 0 \\
& Total & & $\mathbf{2 7}$ & $\mathbf{1 0 0}$ \\
\hline
\end{tabular}

As shown in table 2, after OCS included in Speaking course the percentage of students in high level increased $(77.78 \%)$ and students in the medium level decreased $(22.22 \%)$. 
Table 3 The description of students' speaking score after the implementation of OCS training

\begin{tabular}{|c|c|c|c|}
\hline \multicolumn{2}{|c|}{ Speaking } & \multirow{2}{*}{ Frequency } & \multirow{2}{*}{ Percentage (\%) } \\
\hline Interval & Category & & \\
\hline $80<X \leq 100$ & Very High & 0 & 0 \\
\hline $60<X \leq 80$ & High & 21 & 77.78 \\
\hline $40<X \leq 60$ & Medium & 6 & 22.22 \\
\hline $20<X \leq 40$ & Low & 0 & 0 \\
\hline $0<X \leq 20$ & Very Low & 0 & 0 \\
\hline \multicolumn{2}{|c|}{ Total } & 27 & 100 \\
\hline
\end{tabular}

The results of speaking test show that the students made a slight increase for each indicators (fluency, grammar, vocabulary, details, pronunciation and articulation) in their post test. The comparison of the speaking results is presented in the chart below.

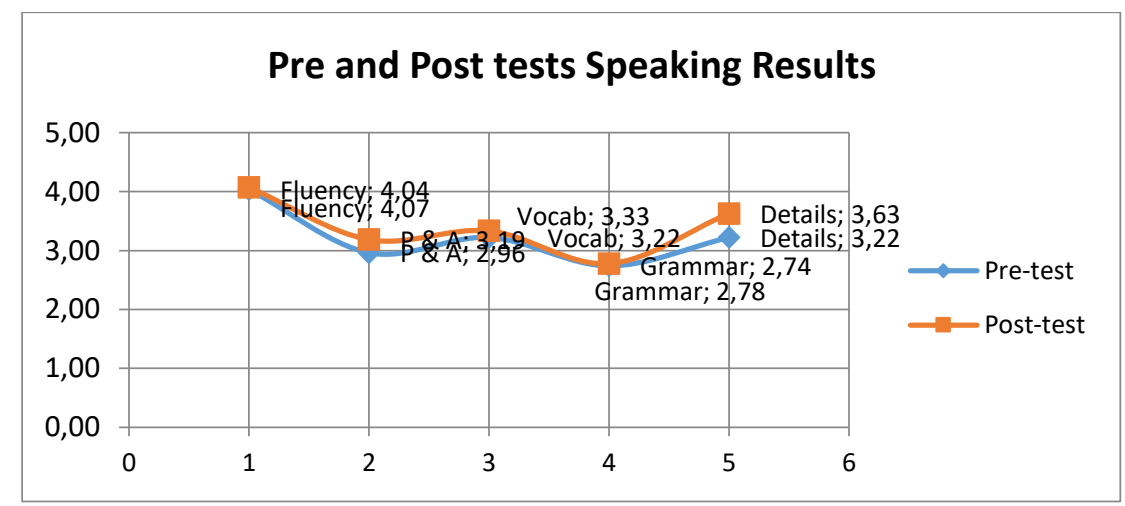

Chart 1 Pre and Post tests Speaking Results

\subsection{What are the oral communication strategies used by the pre-service English teachers}

\section{before and after the implementation of oral communication strategy training?}

In relation to the use of OCS, before the training, students OCS use was on the medium to high level. None of the students were in the very high, low and very low level. The description can be seen on Table 4.

Table 4 The description of students' OCS use before training

\begin{tabular}{ccccc} 
& OCS & & Frequency & Percentage (\%) \\
\cline { 1 - 2 } Interval & & Category & & \\
\hline $80<\mathrm{X} \leq 100$ & Very High & 0 & 0 \\
$60<\mathrm{X} \leq 80$ & High & 16 & 59.26 \\
$40<\mathrm{X} \leq 60$ & Medium & 11 & 40.74 \\
$20<\mathrm{X} \leq 40$ & Low & 0 & 0 \\
$0<\mathrm{X} \leq 20$ & & Very Low & 0 & 0 \\
& Total & & $\mathbf{2 7}$ & $\mathbf{1 0 0}$ \\
\hline
\end{tabular}


After the training, it can be seen than there was a changing in students' OCS use. Table 5 describes that there were students who used OCS in very high level (7.40\%). The number of the students' OCS use in the medium level decreased and the students' OCS use on high level increased.

Table 5 The description of students' OCS use after training

\begin{tabular}{ccccc} 
& \multicolumn{1}{c}{ OCS } & & Frequency & Percentage (\%) \\
\cline { 1 - 2 } Interval & Category & & \\
\hline $80<\mathrm{X} \leq 100$ & Very High & 2 & 7.40 \\
$60<\mathrm{X} \leq 80$ & High & 18 & 66.67 \\
$40<\mathrm{X} \leq 60$ & Medium & 7 & 25.93 \\
$20<\mathrm{X} \leq 40$ & Low & 0 & 0 \\
$0<\mathrm{X} \leq 20$ & & Very Low & 0 & 0 \\
& Total & & $\mathbf{2 7}$ & $\mathbf{1 0 0}$ \\
\hline
\end{tabular}

The types of OCS used by the students before and after the training applied were presented in Table 6. The results reveal that before the training was implemented, the majority of the participants considered type of OCS that mostly used by the students to deal with the speaking problem was message reduction. When using these strategies, learners try to avoid a communication breakdown by reducing an original message, simplifying their utterance or using a similar expression which they can use confidently. They prefer to use familiar words and avoid taking risks using unfamiliar ones though sometimes they realize that their utterances are far from their communication goal. While the least used strategies were social-affective and. The social-affective strategies are strategies that learners applied in order to communicate smoothly, and learners try to control their anxiety and enjoy the process of oral communication. The next strategies which were also used the least were an attempt to think in English. These strategies show learners' attempt to think in English instead of their first language (L1). They have a negative attitude in thinking in L1, and they try to construct sentences in English.

Meanwhile, after the training, non-verbal strategy while speaking was the most frequently used strategy. These strategies are associated with gestures or facial expressions to give hints and help listeners guess what they want to say. One of the examples is the use of eye contact to attract of listener. Message Abandonment became the least used strategy after the training was implemented. These strategies are very common among low proficiency and novice speakers. Learners tend to apply these strategies as they face difficulties in executing their original verbal plan. They tend to give up their communication, leave the message unfinished or seek help from others to continue the conversation. 
Table 6 OCS Types Before and After the OCS Training Included

Oral Communication

\begin{tabular}{|c|c|c|c|c|}
\hline Strategy & Before & Rank & After & Rank \\
\hline \multicolumn{5}{|l|}{ Speaking } \\
\hline Social-affective & 3.43 & 6 & 3.69 & 5 \\
\hline Fluency-oriented & 3.52 & 4 & 3.72 & 4 \\
\hline Negotiation for meaning & 3.54 & 3 & 3.77 & 2 \\
\hline Accuracy oriented & 3.35 & 7 & 3.59 & 6 \\
\hline Message reduction & 3.77 & 1 & 3.75 & 3 \\
\hline Non-verbal Strategy while & 3.65 & 2 & 3.80 & 1 \\
\hline \multicolumn{5}{|l|}{ Speaking } \\
\hline Message abandonment & 3.44 & 5 & 3.29 & 8 \\
\hline Attempt to think in English & 3.43 & 6 & 3.43 & 7 \\
\hline \multicolumn{5}{|l|}{ Listening } \\
\hline $\begin{array}{l}\text { Negotiation for Meaning while } \\
\text { Listening }\end{array}$ & 3.33 & 5 & 3.55 & 5 \\
\hline Fluency maintaining Strategies & 3.16 & 6 & 3.41 & 7 \\
\hline Scanning Strategies & 3.52 & 4 & 3.58 & 3 \\
\hline Getting the gist & 3.09 & 7 & 3.57 & 4 \\
\hline Non Verbal Strategies while Listening & 3.89 & 1 & 3.80 & 2 \\
\hline Less-active listener Strategies & 3.69 & 3 & 3.44 & 6 \\
\hline Word oriented & 3.75 & 2 & 3.83 & 1 \\
\hline
\end{tabular}

In dealing with listening problems, Non-Verbal Strategies while Listening was in the first rank before the training. When listening to English, learners are likely to use nonverbal information, such as speaker's eye contact, facial expression, and gestures, to support their comprehension. While the last rank was Getting the gist. The use of skimming skills for listening comprehension is useful strategy for getting the gist of speaker's utterance. Learners pay attention to general information contained in the speech rather than the detailed information. Learners tend to focus on the context and the speaker's previous sentence to guess the overall meaning. In this case, learners are activating their schemata of background information.

After the training, it can be seen from Table 6 that Word oriented became the most frequently used strategies. They focus on the words produced by speakers to comprehend the speaker's attention. Meanwhile, a least used strategy was Fluency maintaining Strategies. Learners tend to pay attention to the fluency of conversation flow. They focus on the 
speaker's rhythm, intonation and pronunciation to capture their intention. These strategies reflect learners' contribution to the maintenance of conversation flow as listeners by reacting spontaneously.

\subsection{Is there any significant effect of oral communication strategies training on the speaking performance of the pre-service English teachers?}

Repeated measure MANOVA was conducted to compare male and female students' speaking score and oral communication strategy use before and after oral communication strategy training was included in Speaking III course. As presented in Table 4, results showed that male participants had higher speaking scores $(M=71.43, S D=6.29)$ than the female participants after the oral strategy training included in the Speaking III course $(M=66.80$, $S D=11.47)$. Meanwhile, the oral communication strategies used by the male participants $(\mathrm{M}=$ 65.39, $S D=7.01)$ and female participants $(M=65.41, S D=11.99)$ increased slightly after joining the Speaking III course for six meetings.

Table 7 Descriptive Statistics

\begin{tabular}{llrrr} 
& gender & Mean & Std. Deviation & N \\
\hline speaking_pre & male & 64.5714 & 7.80720 & 7 \\
& female & 64.8000 & 12.14647 & 20 \\
& Total & 64.7407 & 11.04046 & 27 \\
& & & 6.29437 & 7 \\
speaking_post & male & 71.4286 & 11.46895 & 20 \\
& female & 66.8000 & 10.46606 & 27 \\
\hline ocs_pre & Total & 68.0000 & 9.01660 & 7 \\
& male & 61.0229 & 9.04567 & 20 \\
& female & 61.7245 & 8.86872 & 27 \\
\hline ocs_post & Total & 61.5426 & 7.01090 & 7 \\
& male & 65.3957 & 11.98877 & 20 \\
& female & 65.4100 & 10.78781 & 27
\end{tabular}

Table 8 presents the statistical analysis on the overall effect of the OCS training on both male and female groups. It shows that there is a significant difference between the two groups $(\mathrm{F}(1,25)=10.146,>\mathrm{F}$ table $=4.24), \mathrm{P}=.001<.05)$.

Table 8 Repeated Measures MANOVA

\begin{tabular}{|c|c|c|c|c|c|c|c|c|}
\hline Effect & & & Value & $\mathrm{F}$ & Hypothesis df & Error df & Sig. & $\begin{array}{c}\text { Partial Eta } \\
\text { Squared }\end{array}$ \\
\hline \multirow[t]{7}{*}{ Between Subjects } & Intercept & Pillai’s Trace & .982 & $643.389^{b}$ & 2.000 & 24.000 & .000 & .982 \\
\hline & & Wilks’ Lambda & .018 & $643.389^{\mathrm{b}}$ & 2.000 & 24.000 & .000 & .982 \\
\hline & & Roy's Largest Root & 53.616 & $643.389^{\mathrm{b}}$ & 2.000 & 24.000 & .000 & .982 \\
\hline & gender & Pillai’s Trace & .014 & $.164^{\mathrm{b}}$ & 2.000 & 24.000 & .849 & .014 \\
\hline & & Wilks' Lambda & .986 & $.164^{\mathrm{b}}$ & 2.000 & 24.000 & .849 & .014 \\
\hline & & Hotelling's trace & .014 & $.164^{\mathrm{b}}$ & 2.000 & 24.000 & .849 & .014 \\
\hline & & Roy's Largest Root & .014 & $.164^{\mathrm{b}}$ & 2.000 & 24.000 & .849 & .014 \\
\hline
\end{tabular}




\begin{tabular}{|c|c|c|c|c|c|c|c|c|}
\hline \multirow[t]{8}{*}{ Within Subjects } & \multirow[t]{4}{*}{ test } & Pillai's Trace & .766 & $39.377^{\mathrm{b}}$ & 2.000 & 24.000 & .000 & .766 \\
\hline & & Wilks' Lambda & .234 & $39.377^{\mathrm{b}}$ & 2.000 & 24.000 & .000 & .766 \\
\hline & & Hotelling's trace & 3.281 & $39.377^{\mathrm{b}}$ & 2.000 & 24.000 & .000 & .766 \\
\hline & & Roy's Largest Root & 3.281 & $39.377^{\mathrm{b}}$ & 2.000 & 24.000 & .000 & .766 \\
\hline & \multirow[t]{4}{*}{ test*gender } & Pillai’s Trace & .458 & $10.146^{\mathrm{b}}$ & 2.000 & 24.000 & .001 & .458 \\
\hline & & Wilks' Lambda & .542 & $10.146^{\mathrm{b}}$ & 2.000 & 24.000 & .001 & .458 \\
\hline & & Hotelling's trace & .845 & $10.146^{\mathrm{b}}$ & 2.000 & 24.000 & .001 & .458 \\
\hline & & Roy's Largest Root & .845 & $10.146^{\mathrm{b}}$ & 2.000 & 24.000 & .001 & .458 \\
\hline
\end{tabular}

Table. 9 projects the repeated-measures MANOVA for students' speaking ability and oral communication strategy use. The analysis showed significant results on male and female students' speaking before and after oral communication strategy training included in Speaking III course $(\mathrm{F}(1,25)=18.328, \mathrm{p}=.000)$. Meanwhile, repeated-measures MANOVA results on students' oral communication strategies use found the difference to be insignificant between the male and female groups $(\mathrm{F}(1,25)=.021, \mathrm{p}=.885)$.

Table 9 Test between subject effect

\begin{tabular}{cccccccc} 
Source & Measure & $\begin{array}{c}\text { Type III Sum } \\
\text { Of squares }\end{array}$ & df & $\begin{array}{c}\text { Mean } \\
\text { Square }\end{array}$ & F & $\begin{array}{c}\text { Partial Eta } \\
\text { Squared }\end{array}$ \\
\hline Intercept & Speaking & 185654.933 & 1 & 185654.933 & 797.158 & .000 & .970 \\
& ocs & 166675.600 & 1 & 166675.600 & 1145.966 & .000 & .979 \\
\hline gender & Speaking & 50.193 & 1 & 50.193 & .216 & .646 & .009 \\
& ocs & 1.329 & 1 & 1.329 & .009 & .000 \\
\hline Error & Speaking & 5822.400 & 25 & 5822.400 & & & \\
& ocs & 3636.137 & 25 & 3636.137 & &
\end{tabular}

The results suggest that oral communication strategy training affects students' speaking scores but does not affect gender.

\subsection{What are the perceptions of pre-service English teachers concerning the implementation of oral communication strategies training?}

The interview was conducted for two and a half hours. It involved five students who voluntarily joined the interview. Questions designed for the interview mainly focused on the students' attitude towards the Speaking III course and the inclusion of Oral Communication Strategy Training in the Speaking III course. The interview results revealed several points regarding students' attitude on the inclusion on OCSI in Speaking III course. In general, from the students' responses, it can be assumed that they have a positive attitude towards Speaking III course and the inclusion of OCSI. The students had different lecturer when they were in Speaking 1 and 2 courses therefore in Speaking III course they got to know with new lecturer and different ways of teaching. This condition seemed affected the students' views towards the course. The views of the students could be seen from their attitudes. These three 
components reflected the students' views towards Speaking III course, the lecturer, and the implementation of OCS.

\subsubsection{Cognitive}

A cognitive component is made up of the beliefs, ideas, or opinions about the object of the attitude. The excerpts below show student's opinion on Speaking III course and the implementation of OCS, respectively.

"I think from Speaking III class I got new way to learn speaking as in the previous speaking classes I was very quiet. In Speaking III, I speak better as the lecturer encouraged us to speak and how to construct our argument (S4, L5-L20-25, AC)."

Students' opinions with regards to the use of oral communication strategies are identified in the following excerpts.

"The strategies training encourages us to speak better, and it helps the speaker to send the message across (S2, L86-L89, AC)."

"The strategies pushed us to maintain our communication, so we do not just leave our sentences unfinished (S3, L95-L98, AC)."

\subsubsection{Affective}

The affective component of attitude refers to the feelings and emotions that one has towards an object, "likes" or "dislikes", "with" or "against".

"The thing that I like from Speaking III class is we were taught to be more interactive with others (S1, L5-L6, AA)."

"What I like in Speaking III is Ms. Nita is very fluent and I like the way she teaches us. She teaches us to understand a topic better. (S2, L11-L12, $A A)$."

"I like Speaking III because it is more attractive (S3, L17, AA)."

"The material in Speaking III is more structured. The lecturer gave assignment almost every week. We were encouraged to speak and speak (S5, L27-L30, AA)."

From the excerpts above, the students like the Speaking III course because the lecturer has good personality, fluent in English, and created a positive atmosphere in the classroom by providing different teaching strategies and encouragement to the students. Thus, the students had a positive attitude towards the Speaking III course, which 
encouraged them to be willing to speak and felt motivated to join different activities in the Speaking III course.

\subsubsection{Behavioural}

The behavioural component deals with one's behavioural intentions towards the object. In relation to behavioural aspect of attitude, the following extracts show what the students did when facing problems in oral communication.

"I got assignment in Speaking III to interview seniors about learning English. In the middle of the interview, I couldn't hear what the senior said, so I said "Pardon me, can you repeat your sentence again?". In another interview, when I asked question to the senior, it seemed that the senior did not understand my question, so I restated my question again to make him understand (S2, L44- L51, AB).”

"In oral interaction, for example in the interview that I did with the senior, there were times when I repeated my questions to make her understand (S5, L53-L55, AB).”

"I used a lot of fillers when I could not say what I want to say. I used it until I regained the point that I want to express (S2, L70-L72, AB)."

"When I had problem understanding what people said, I tried to relate the words with the context (S3, L80-L82, AB)."

The above extracts showed oral communication strategies that the students performed during conversation in order to achieve the goal of communication. The strategies that the students applied were categorized as positive strategies.

The interview also identified that the students applied non-verbal strategies during oral communication as seen in the following extracts.

"In the interview, I remembered that I moved my hand to sign to the interviewee to speak louder. When they stopped at certain point, I also moved my hand to asked them to keep talking (S1, L60-L63, AB, NV)."

"I used gesture, like moving my hand as sometimes the interviewee did not know what I said (S3, L65-L67, AB, NV)."

In the extracts above, the students mentioned that gesture, particularly moving their hand to signal the interlocutor to continue their speech. 
It was also identified that students also applied negative strategies while facing communication problems.

"When I had conversation with my friends in English, sometimes I got very nervous and suddenly I forgot what I want to say. I stopped and I said thank you (S1, L75-L79, AB, NS).”

\section{DISCUSSION}

The discussion of this section elaborates the findings from different sets of data, namely students' responses on OCSI, students' Speaking test scores, and the interview results. This section will be presented based on the research questions formulated in this study, they are: 1). the oral communication strategies use and Speaking performance of the pre-service English teachers, 2). the effect of oral communication strategies training on the speaking performance of the pre-service English teachers, 3). the role of gender in the use of oral communication strategies by pre-service English teachers and 4) the pre-service English teachers' views to the implementation of oral communication strategies training.

This part tries to address the first issue raised in the first research problem, the Oral communication Strategies use and Speaking performance of the pre-service English teachers before and after the inclusion of Oral Communication Strategy Training.

Language learners, in general, employ CSs during language communication when they are aware of their influence and have some control over their selection and use (Manchón, et al., 2000; Faucette,2001). As a result, researchers advocate for training in the use of CSs, claiming that they result in more successful communication. Maleki (2007) stated that teaching communication skills is useful from a pedagogical standpoint and promotes language learning. According to him, language instruction materials that incorporate communication tactics outperform those that do not. It is worth noting that Faucette (2001) demonstrated the benefits of CS education by observing the popularity of CS instruction in the EFL situation in Japan since the early 1990s.

This study showed a slight increase in the average score of the students' OCS use after the training was included. In addition, it was also found that after the training, the number of students who were in high and very high level increased than before the training. This finding implied that learners could transfer and utilize what they have taught from the strategy training.

In relation to the most frequently used OCS, it was noted that the types of OCS before and after the training were different for both strategies for coping with speaking and listening 
problems. Before the inclusion of the training, the type of OCS that mostly used by the students to deal with speaking problem was message reduction while the least used strategies were social-affective and attempt to think in English. Meanwhile, after the training, nonverbal strategy while speaking was frequently used by the students. Message Abandonment became the least used strategy after the training implemented.

The results of speaking test showed that in general there was an increase on the students speaking performance. The students slightly increased each indicator (fluency, grammar, vocabulary, details, pronunciation and articulation) in their post-test.

This section attempts to answer the second research question: the effect of oral communication strategy training on the speaking performance of pre-service English teachers. The analysis results of independent samples t-tests show a significant difference in the students' speaking performance before the inclusion and after it was applied. This means that the inclusion of Oral Communication Strategy Training for six meetings in Speaking course in this study had an effect on the students' speaking. It is possible that the instruction and practice of the oral communication strategies for six weeks might have raised the students' awareness of the use of these strategies and motivate them to speak in Speaking III course. The benefits of the CS instruction have also been supported by many previous researchers (Nakatani, 2005; Maleki, 2007; Kongsom, 2009; Lam, 2010; Maleki, 2010; Mariani, 2010). Most findings of the past research works (e.g. Dörnyei, 1995; Nakatani, 2005; Maleki, 2007; and Kongsom, 2009) found that language learners who received instruction in communication strategies made significant improvements in their approach use and speech performance on both a qualitative and quantitative level.

However, the analysis of independent samples t-test on the use of OCSs reported that there was no significant effect on the number of CSs before and after the inclusion of OCS training. This result is different from a study conducted by Sukirlan (2014), who indicated an increase in the number of certain communication strategies used by the students. The difference occurred might be caused by the short period used by the researchers in inserting the OCS in Speaking III course. Longer period may yield different findings.

The results concerning the role of gender in the pre-service English teachers' use of oral communication strategies revealed that there was no significant difference in the use of oral communication strategies training by male and female pre-service English teachers. This finding was contradict with results from Mizaei and Heidari (2012), who found that male and 
female learners preferred different types of oral communication strategies while coping with speaking and listening problems.

The views of pre-service English teachers on the implementation of oral communication strategies training in the Speaking III course were identified from the changes in their attitudes which are considered as components of motivation in language learning (Gardner, 1985). Students with positive attitudes tend to be attentive and involved in classroom activities arranged by the teacher. Their willingness to participate indirectly encouraged them to be in oral interaction with their friends in the classroom. In this study, the students were actively involved in different activities assigned by the teachers and communicated enthusiastically using English with their friends while they tried to accomplish the assignments given. The students' motivation and willingness to communicate in English seemed to be in line with a study by Peng (2007) which examined students' willingness to communicate in English and motivation indicated a high correlation between motivation and students' willingness to communicate in English. Her conclusion corroborated a statement of Hynes (2011), stating that a lack of motivation is another impediment to learning, whereas a lack of willingness is a motivation-related willingness. A study by Huang (2010) also confirmed that motivation was a powerful factor in oral communication strategy use. Consequently, it makes sense to say that students who held positive attitudes and strong motivation to acquire language will be more willing to practice using the language without fear making mistakes. Their positive attitudes also encourage them to use more self-reliant strategies than those with negative attitudes. Oxford (1990) states that more motivated students used a greater variety of tactics than less motivated students. According to a study by Oxford and Nyikos (1989, p. 294), The degree of professed desire to learn the language exerted the greatest influence on strategy selection.

Another possible explanation for the researcher's findings involving attitudes and speaking performance is that their earlier learning experiences influence the students' attitude toward speaking English. In relation to this point, Cook (2001) claims that just because students learned something in class does not mean it is equally beneficial for all of them because their minds work differently. Students base their actions on their prior experience with language learning and use. Decision to choose a particular strategy in response to a problem or communicative situation is influenced by a number of elements, including the context in which the strategy is used, the speakers' personalities, their competence level, and the instructional technique to which learners are exposed. This demonstrates that successful 
language learners are more likely to have a favourable attitude toward speaking English. Additionally, language learners who had a favourable experience learning English are more likely to have a favourable attitude toward speaking English. In other words, earlier learning experiences influence students' attitudes toward speaking English and their choice of communication strategies. Several researchers (Robertson et al, 2000; Hellsten, 2002; Wong, 2004; and Sawir, 2005) have attempted to elucidate language learners' challenges with the language. They discovered that language learners lack confidence while speaking English due to earlier educational experiences in which English teachers concentrated mostly on grammar and reading skills rather than conversational skills (Wong, 2004; and Sawir, 2005). Sawir (2005) additionally, it was indicated that this notion expressed itself in students' communication behaviour, impairing their ability to interact successfully socially and intellectually and retarding their acquisition of conversational skills.

\section{CONCLUSION}

Referring to the results of this study, it is suggested to design training with a longer period of time and different structures. The short period of OCS training implementation seemed to not affect students as students had minimum opportunity to be aware of using the communication strategies whenever they face problem in oral communication. Extending the training time will help the students be more familiar with the strategies and use them. The different training structure is applied in order to make the training more effective for the students. Having a positive attitude had triggered students' motivation and willingness to use English more. The teacher's encouragement in using English indirectly raised students' awareness in using oral communication strategies to send their message across while they were facing problems during oral communication.

\section{REFERENCES}

Adler, R. B., Rodman, G. R., \& Du Pré, A. (2016). Understanding human communication (Vol. 13). Oxford: Oxford University Press.

Aziz, Z., Fata, I. A., \& Balqis, S. (2018). "Wait, how do I say that in English?" Communication strategies for English as a foreign language learners. Lingua Cultura, 12(2), 149-154. https://doi.org/10.21512/lc.v12i2.3745

Bachman, L. F. (1990). Fundamental considerations in language testing. Oxford: Oxford University Press.

Bialystok, E.1990. Communication strategies: A psychological analysis of second language use. London: Blackwell. 
Cahyono, B.Yudi \& Widiati, U. (2008). The teaching of efl vocabulary in the Indonesian context: The state of the art. TEFLIN Journal, 19 (1), 1-17. http://dx.doi.org/10.15639/teflinjournal.v19i1/1-17

Canale, M., \& Swain, M. (1980). Theoretical bases of communicative approaches to second language teaching and testing. Applied linguistics, 1(1), 1-47.

Candlin, C.N. (1983). Syllabus design as a critical process. Paper presented at the Colloquium on Syllabus/Curriculum Design, 17th Annual TESOL Convention, Toronto.

Cook, V. (2001). Using the first language in the classroom. Canadian modern language review, 57(3), 402-423. https://doi.org/10.3138/cmlr.57.3.402

Creswell, J. W., \& Clark, V. L. P. (2007). Designing and conducting mixed methods research. Thousand Oaks, CA: Sage Publications.

Dörnyei, Z. (1995). On the teachability of communication strategies. TESOL Quarterly, 29(1), 55-85. https://doi.org/https://doi.org/10.2307/3587805

Dornyei, Z., \& Scott, M. L. (1997). Communication strategies in a second language: Definitions and taxonomies. Language Learning, 47, 173-210. http://dx.doi.org/10.1111/0023-8333.51997005

Dörnyei, Z. (2007). Research methods in applied linguistics: Quantitative, qualitative, and mixed methodologies. Oxford: Oxford University Press.

Ellis, R. 1990: Instructed second language acquisition. Oxford: Basil Blackwell.

Ellis, R. (1994) The Study of Second Language Acquisition. Oxford University.

Faerch, C. (1983). Plans and strategies in foreign language communication. London. Longman.

Faucette, P. (2001). A pedagogical perspective on communication strategies: Benefits of training and an analysis of English language teaching materials. Second Language Studies19(2), 1-40.

Gardner, R. C. (1985). Social psychology and second language learning: The role of attitudes and motivation. London: Edward Arnold.

Hellstén, M. (2002). Students in transition: Needs and experiences of international students in Australia.

Huang, C. (2010). Exploring factors affecting the use of oral communication strategies. Long HuaTechnology University Journal, 30, 85-104.

Ivankova, N \& John W.C. (2009). Mixed methods. Qualitative research in applied linguistics : A practical introduction, edited by Juanita H \& Robert A.C. Hampshire: Palgrave Mcmillan. 
Kongsom, T. (2009). The effects of teaching communication strategies to Thai learners of English. Language education today: Between theory and practice, 154.

Maleki, A. (2007). Teachability of communication strategies: An Iranian experience. System, 35(4), 583-594. https://doi.org/https://doi.org/10.1016/j.system.2007.04.001

Manchón, R. M., Roca de Larios, J., \& Murphy, L. (2000). An approximation to the study of backtracking in L2 writing. Learning and Instruction, 10(1), 13-35. https://doi.org/https://doi.org/10.1016/S0959-4752(99)00016-X

Morse, J. M. (1991). Approaches to qualitative-quantitative methodological triangulation. Nursing research, 40(2), 120-123.

Nakatani, Y. (2006). Developing oral communication strategy inventory. The Modern Language Journal. $90 \quad$ (2), 151-168. https://doi.org/10.1111/j.15404781.2006.00390.x

Nakatani, Mkki, \& Bradley. (2012). 'Free' to choose: Communication strategy use in efl classrooms in Iran. Iranian Journal of Applied Linguistics (IJAL), Vol. 15, No. 2, 6183.

O’Connor, K., Greene, H., \& Anderson, P. (2006). Action Research: A Tool for Improving Teacher Quality and Classroom Practice. Ontario Action Researcher.

Ogili, E. (2005). Strategies for effective communication of educational instructions in Nigeria. Malaysian Online Journal of Instructional Technology (MOJIT), 2(1), 1-7. Oxford University Press.

Oxford, R., and Nyikos, M. (1989). Variable affecting choice of language learning strategies by university students. The Modern Language Journal, 73(3),291-300.

Pachler, N., Evans, M., \& Lawes, S. (2007). Modern foreign languages: Teaching school subjects, 11-19. Routledge.

Peloghitis, J. (2006). Enhancing communication through the use of foreigner interviews. Journal of NELTA, 11(1-2), 47-51.

Peng, J. (2007). Willingness to communicate in an L2 and integrative motivation among college students in an intensive English language program in China. University of Sydney Papers in TESOL, 2, 33-59.

Rachmawaty, N. \& Hermagustiana, I. (2010). Does retelling technique improve speaking fluency? TEFLIN Journal, 21 (1), 1-8.

Richards, L. (2009). Handling qualitative data: A practical guide (2nd ed.). London: Sage Publications, Inc.

Robertson, M., Line, M., Jones, S., \& Thomas, S. (2000). International Students, Learning Environments and Perceptions: A case study using the Delphi technique. Higher 
Education Research \& Development, 19(1), 89-102. https://doi.org/10.1080/07294360050020499

Sawir, E. (2005). Language difficulties of international students in Australia: The effects of prior learning experience. International education journal, 6(5), 567-580.

Sayuri (2016). English speaking problems of efl learners of Mulawarman university. Indonesian Journal of EFL and Linguistics, Vol. 1 (1) p.47-61.

Scarcella, R. \& Oxford, R., 1992: The tapestry of language learning: The individual in the communicative classroom. Boston: Heinle \& Heinle.

Selinker, L. (1972). Interlanguage. IRAL 10 3: 209-230.

Setiyadi, Ag. B. (2009). Language learning strategy questionnaire (LLSQ): Step towards the success in teaching English. Presented at the Professorship Inauguration, November 24, 2009. Bandar Lampung. Lampung Univerisity Press.

Shin, S. (2008). Preparing non-native English speaking ESL teachers. Teacher Development, 12, (1), 57-65. https://doi.org/10.1080/13664530701827749

Silverman, D. (2001). Interpreting qualitative data: Methods for analysing talk, text and interaction. Great Britain: Sage Publication Ltd.

Sukirlan, M. (2014). Teaching communication strategies in an EFL class of tertiary level. Theory and Practice in Language Studies, 4(10), 2033.

Teddlie, C., \& Tashakkori, A. (2003). Major issues and controversies in the use of mixed methods in the social and behavioural sciences. Handbook of mixed methods in the social \& behavioural sciences (pp. 3-50). Thousand Oaks, CA: Sage.

Thalal, M. (2009). New insights into teaching of English language to Indonesian students. Progresif: Journal of Multiperspective Education, 1(1), 1-160.

Toomnan, P. \& Intaraprasert, C. (2015). The Impacts of Attitudes towards Speaking English on the Use of Communication Strategies by English Majors in Thailand. Theory and Practice in Language Studies, Vol. 5, No. 6, pp. 1151-1158. http://dx.doi.org/10.17507/tpls.0506.04

Willems, G. M. (1987). Communication strategies and their significance in foreign language teaching. System, 15(3), 351-364. https://doi.org/https://doi.org/10.1016/0346251X(87)90009-1

Wong, B., \& Wong, B. Y. (Eds.). (2004). Learning about learning disabilities. Academic press.

Zhao, T. \& Intaraprasert, C. (2013). Use of Communication Strategies by Tourism-oriented EFL learners in Relation to Attitude towards English Speaking and English Language and Exposure to Oral Communication in English. International Journal of Scientific and Research Publications, 3 (5), 1-8. https://doi.org/10.5539/elt.v6n7p46 